\title{
Rainfall and land use empirically coupled to forecast landslides in the Esino river basin, central Italy
}

\author{
E. Gioia, T. Carone, and F. Marincioni \\ Department of Life and Environmental Sciences, Università Politecnica delle Marche, Ancona, Italy \\ Correspondence to: F. Marincioni (f.marincioni@univpm.it)
}

Received: 31 January 2015 - Published in Nat. Hazards Earth Syst. Sci. Discuss.: 24 February 2015

Revised: 28 May 2015 - Accepted: 01 June 2015 - Published: 19 June 2015

\begin{abstract}
A coupled empirical approach to highlight relationships between rainfall, vegetation segmentation, and landslide occurrence is discussed. To reveal such links, two important rainfall events, which occurred over the Esino river basin in central Italy in November 2013 and May 2014, were analysed. The correlation between rainfall and landslides was evaluated by applying an intensity-duration (ID) threshold method, whereas the correlation between vegetation segmentation and landslides was investigated using morphological spatial pattern analysis (MSPA). This coupled approach represents an attempt to find both timing and location of landslide occurrence through an empirical (black box) analysis. Results showed: (i) the ID minimum threshold proposed in a previous study (Gioia et al., 2015) to be verified as an effective equation to assess the rainfall conditions likely to trigger landslides in the study area ("when"), and (ii) the core areas and the fragmented vegetation structures defined by the MSPA to be the most affected by slope failures ("where"). These encouraging findings prompt additional testing and the application of such a coupled empirical approach so that it is possible to achieve an integrated basis for landslide forecasting.
\end{abstract}

\section{Introduction}

Landslides are common phenomena in Italy and in the Marche region. According to a 2008 report on hydrogeological hazards by the Italian Ministry of Environment, about $99 \%$ of the municipalities in this region are prone to mass movements, and indeed $91 \%$ of these towns have been affected by landslides (Ministry of Environment Territory and Sea, 2008).
Undeniably, each landslide occurrence responds to generally known triggering factors and specific predisposing local conditions. Among the most studied of these are rainfall (e.g. Guidicini and Iwasa, 1977; Caine, 1980; Wilson and Wieczorek, 1995; De Vita and Reichenbach, 1998; Giannecchini, 2006; Guzzetti et al., 2007; Cucchi et al., 2015; Segoni et al., 2015) and vegetation cover (e.g. Istanbulluoglu and Bras, 2005; Marston, 2010; Kai et al., 2014). Land use change is also recognized as an important factor influencing mass movements (e.g. Cruden and Varnes, 1996; Strudley et al., 2008; Fell et al., 2008; Wasowski et al., 2010). To this extent an interesting aspect, though little explored, is the characterization of the vegetation cover in rainfall-triggered landslide areas, using segmentation methods based on digital images.

This paper proposes an empirical (black box) approach to identify the influence of both rainfall and vegetation segmentation on landslide occurrence. Two recent rainfall events that triggered widespread landslides over the Esino river watershed, central Italy, were studied by applying the intensityduration rainfall statistical model (Caine, 1980) and morphological spatial pattern analysis (MSPA) integrated with a geographic information system (GIS) (Soille and Vogt, 2009; Vogt, 2014); the former method was used to define a rainfall threshold, the latter to detect the vegetation segmentation patterns more subjected to slope failures. The analyses were performed in the mountain and low hill areas of the basin.

Authors are aware that landslide initiation is the result of numerous factors dynamically interacting over broad spatial and temporal scales, and the mere exploration of a few predisposing factors, such as rainfall intensity-duration or vegetation segmentation, cannot provide an overall landslidetriggering model. However, the promising correlations be- 
tween rainfall, land use, and landslide occurrence found in this study prompt further investigations of the proposed coupled empirical approach, which could certainly contribute to a better understanding of slope dynamics and possibly advance landslide hazard mapping within the study area.

\section{The area and rainfall events studied}

The Esino river basin was selected because it is one of the largest and most inhabited watersheds of the Marche region (National Institute of Statistics - ISTAT, 2014), it is continuously monitored, and data on past rainfall events and landslide occurrences are readily available. Similarly, the November 2013 and May 2014 rainfall events were chosen for this study because they affected the entire Marche region and the effects were well-documented. These two events were also selected because they occurred subsequent to the 1953-2011 period, for which the intensity-duration threshold over the study area had already been developed by a previous investigation (Gioia et al., 2015).

The Marche region is located around latitude $43^{\circ} \mathrm{N}$ and longitude $14^{\circ} \mathrm{E}$, with a total surface area of $9385 \mathrm{~km}^{2}$, and has 1565000 residents. The regional climate is affected by the presence of the Adriatic Sea to the east and the Apennines mountains chain to the west. From east to west, the region can be subdivided into three different climatic and geomorphological areas: coastal, low hills, and mountains. Low hills, prevalently composed of clayed sandstone sediments, represent $69 \%$ of the territory; $31 \%$ is mountains, largely composed of massive limestone. Only a small portion represents coastal morphology along the Adriatic seaboard. Finally, about $30 \%$ of the territory is covered by forests.

The Esino watershed extends approximately $1223 \mathrm{~km}^{2}$ and is inhabited by about 440000 people. Its lithology is characterized by almost exclusively sedimentary rocks roughly divided into (i) carbonate, (ii) terrigenous, and (iii) postorogenic sediments (Coltorti and Nanni, 1987; Gentili and Dramis, 1997). The carbonate rocks prevail in the basin's westward section of the mountainous Umbro-Marchean ridge. The terrigenous sediments dominate the hilly central Marchean ridge area, and a post-orogenic complex of clays, silts, sands, and conglomerates covers the low hills in the eastward section of the basin, from the sub-Apennine hills to the Adriatic coast (Gentili and Dramis, 1997). For this study, the Esino river basin was divided into two sections of approximately the same size: (i) mountains - western part, mainly composed of carbonate sediments, and (ii) low hills - eastern part, mostly characterized by post-orogenic and terrigenous sediments (Fig. 1).

The first studied rainfall event, which developed over the period 10-13 November 2013, brought widespread and persistent precipitation, with a maximum of $499 \mathrm{~mm}$ of rain over the Sibillini Mountains (CFRM, 2013) causing several, yet contained floods and extensive slope failure phenomena throughout the region. Within the Esino river basin, numerous landslide reports were collected by the local civil protection monitoring and forecasting service (Centro Funzionale Multirischi della Regione Marche - CFRM), especially in the mountains where the highest cumulative rainfall was registered. The second studied rainfall event developed over the period 2-4 May 2014, and was characterized by particularly intense rainfall that persisted on the low hills over the eastern portion of the region. The most intense rainfall occurred in the first $6 \mathrm{~h}$ of 3 May, with a maximum of $161 \mathrm{~mm}$ of rain over the low hill area of Pesaro. The main damages were caused by the flooding of the Misa river in Senigallia (located north of the Esino) and the overflowing of the Triponzio channel (a tributary of the Esino river). In addition, numerous landslides were recorded across the Marche region in connection with this rainfall event. Within the Esino river basin, the majority of landslides occurred mainly in the low hill area rather than in the mountains (CFRM, 2014).

\section{Methods}

\subsection{Intensity-duration (ID) analysis}

Rainfall data were downloaded from an online database made available by the CFRM, which manages a network of rain gauges distributed fairly homogeneously over the study area. Landslide data and information were gathered from reports also made available by the CFRM. Collected data were georeferenced in the Gauss-Boaga coordinate system and digitalized into a GIS environment. Each landslide was then paired to a rain gauge station using a criterion of proximity.

The correlation between rainfall and landslides was studied by applying the intensity-duration (ID) threshold methodology developed by Caine (1980). The ID threshold assumes the general form of the following equation:

$I=c+\alpha \times D^{-\beta}$,

where $I$ is the rainfall intensity (in $\mathrm{mm} \mathrm{h}^{-1}$ ), $D$ is the rainfall duration (in h), and $c, \alpha$, and $\beta$ are empirical parameters of the specific site conditions.

In particular, in this study the performance of the ID threshold, modelled by Gioia et al. (2015), was tested through statistical analysis of mostly shallow landslides activated in the low hill section of the Esino river basin over the period 1953-2011:

$I=1.61 \times D^{-0.21} \quad(4<D<167)$,

where $I$ is the mean rainfall intensity in $\mathrm{mm} \mathrm{h}^{-1}$ and $D$ is the rainfall duration in hours.

The data collected during the 2013 and 2014 events, once plotted into the Gioia et al. (2015) intensity-duration logarithmic graph, could further validate Eq. (2) as an effective ID threshold over the entire river basin. 


\subsection{Morphological spatial pattern analysis (MSPA)}

The MSPA (Soille and Vogt, 2009) was performed over the study area's anthropogenic agricultural land cover categories (e.g. mixed cultivations, crops, shrubs, mixed forests or grasslands) by using the open source software GUIDOS 2.0. (Vogt, 2014). Land cover information was derived from a Corine land cover map (available at: http://www.sinanet. isprambiente.it). Data were then integrated in a GIS environment.

All the agricultural land cover categories concerned were first transformed into binary images ( 1 is the presence of the cover; 0 , the absence of the cover), then, through the MSPA were segmented in different patterns to highlight information on vegetation structures. Such patterns are mutually exclusive and, if merged, match the initial area. Soille and Vogt (2009) described these segmentation types as follows:

- core - the innermost part of a vegetation patch, excluding the foreground perimeter that has to be greater than an established minimum size;

- islet - a portion of the vegetation cover that is too small to contain a core area;

- edge - the perimeter of a core area;

- perforation - a hole in the vegetation cover;

- bridge - a connector (long-limbed vegetation patch) between different core areas;

- loop - a connector whose ends are located in the same core area;

- branch - a connector whose ends bond a core area and another connector, an edge or a perforation.

By overlapping such a MSPA map to the landslide distribution map of the November 2013 and May 2014 rainfall events, the vegetation segmentation patterns more subjected to slope failures were highlighted. The results of this study were then compared with those of Carone et al. (2015) who already performed multitemporal MSPA over the Marche region for the period 2000-2006. Carone et al. (2015) pointed out a higher number of landslides in edge, branch, and bridge patterns, which represents areas of transition between different covers, whereas crop covers showed a great landslide occurrence in core areas.

\section{Results and discussion}

The rainfall event of November 2013 triggered 35 landslides; 3 in the low hills, and 32 in the mountains, whereas the event of May 2014 triggered 20 landslides; 19 in the low hills and 1 in the mountains (Fig. 1). In terms of movement typology, they are mostly slides and flows, yet it is important

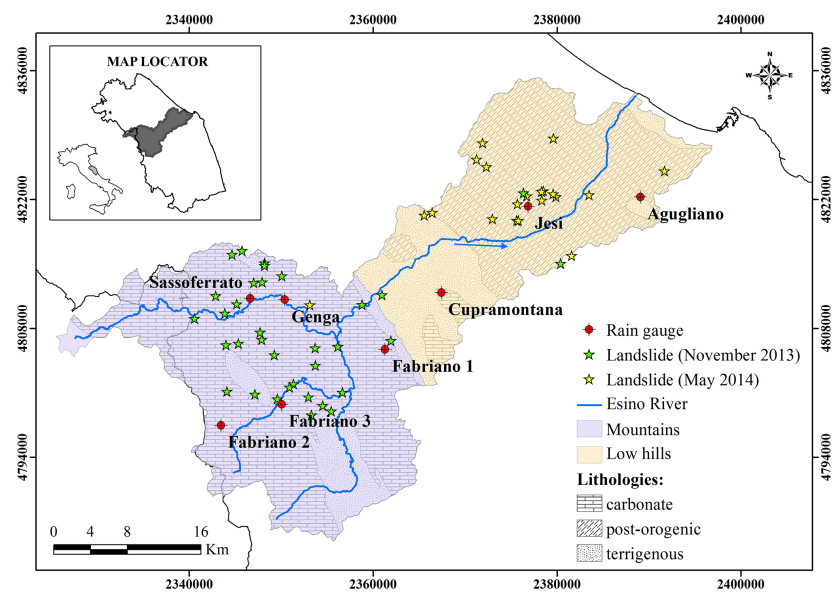

Figure 1. Study area: the Esino river basin, divided into mountain (purple) and low hill (light brown) areas. Map also shows the main lithologies of the study area, the names and the locations of the selected rain gauge stations, and the landslides triggered during the events of November 2013 and May 2014

to point out that this information was obtained from reports by the Centro Funzionale Multirischi della Regione Marche (CFRM), which mainly collects data about landslide events that impact human activities and infrastructures (e.g. agricultural covers, roads, residential buildings).

Table 1 lists the average rainfall intensities and durations logged by the rain gauge stations, while Fig. 2 plots new and historic data (Gioia et al., 2015) in relation to the threshold defined by Eq. (2). For the event of November 2013 (Table 1), the maximum range $\left(2.4-4.6 \mathrm{~mm} \mathrm{~h}^{-1}\right)$ of mean rainfall intensity was registered within the mountains. The rain gauges recording the minimum (Fabriano 2) and maximum (Sassoferrato) intensity values also accounted for the lowest (1) and the highest number (14) of landslides. The duration (rainy hours) of the rainfall event was relatively uniform over the entire watershed (60-69h). The plot of the ID data, shown in Fig. 2, highlights that all the values are located well above the Gioia et al. (2015) threshold. This confirms the feasibility of Eq. (2) as a minimum threshold for both the mountain and low hill areas. Furthermore, all the ID data of November 2013 were plotted over the cloud of historical rainfall events that triggered landslides in the study area. Such detail is an indication of the great magnitude of the 2013 event, with intensities and durations higher than ever recorded, and possibly further evidence of a changing climate. Moreover, the particular rainfall variability of the mountains data along the $y$ axis (mean intensity), underlines how a single rainfall event can change its intensity within a relatively small area, and can trigger a very different number of landslides, such as for example, those recorded near Fabriano 2 and Sassoferrato gauging stations (Table 1).

For the event of May 2014 (Table 1), the values of mean rainfall intensity are relatively uniform over the entire wa- 


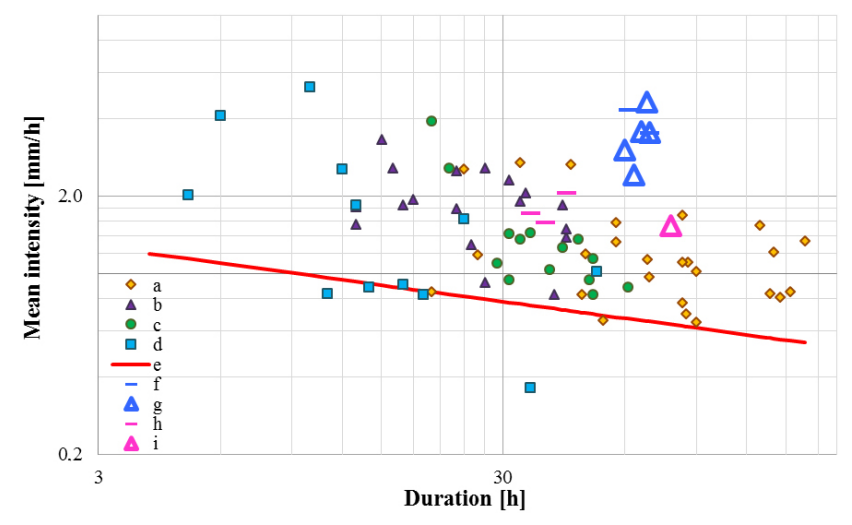

Figure 2. Intensity-duration logarithmic graph modified according to Gioia et al. (2015). Figure shows the comparison between the ID values of historical rainfall events (a-d), the ID threshold (e) and the ID data of the November 2013 (f, g) and May 2014 (h, i) rainfalls. The historical rainfall events are represented according to the number of landslides triggered: (a) main events that triggered more than 10 landslides, (b) secondary events that triggered 3-9 landslides, (c) minor events that triggered 2 landslides, and (d) single events that triggered 1 landslide. The ID data of November 2013 and May 2014 are differentiated according to the rain gauge locations: low hills (f, h) or mountains $(\mathbf{g}, \mathbf{i})$.

tershed, showing a minimum in the rain gauge of Genga $\left(1.5 \mathrm{~mm} \mathrm{~h}^{-1}\right)$, in the mountains, and a maximum in Jesi $\left(2.1 \mathrm{~mm} \mathrm{~h}^{-1}\right)$, in the low hills. On the other hand, a higher variability is observable in terms of durations (rainy hours). The rainfall events in the eastern part of the watershed lasted between 35 and $43 \mathrm{~h}$, while in the western part they lasted 78 h. Figure 2 displays this variability on the $x$ axis (duration). Also, for this event the plot of the ID data is located above the threshold, thus validating Eq. (2) in both the mountains and low hill areas of the Esino river basin. In addition, the ID data of the May 2014 event fall within the cloud of ID values that have triggered landslides in the past. Thus, it is possible to compare the effects of the historical rainfalls with the ones studied. Indeed, the ID values registered in Agugliano and Cupramontana (i.e. the lowest pink dashes in Fig. 2), to each of which were paired two landslides (Table 1), are similar to those of past minor rainfall events (those triggering two landslides). Furthermore, the ID values of the Jesi gauging station (i.e. the upper pink dash in Fig. 2), to which were paired 15 landslides (Table 1), are similar to those of the past main rainfall events (those triggering more than 10 landslides). These results suggest that in the low hill areas, the number of landslides triggered by a rainfall event is linked to a specific range of ID values. This is not true in the mountain area. As a matter of fact, the ID values logged in the mountainous Genga gauging station (Table 1) would foretell, according to Fig. 2, a high probability of 10 landslides or more, yet only one mass movement was recorded. Indeed, the effect of precipitation on slope stability depends on local conditions, including soil characteristics. This result
Table 1. Values of rainfall mean intensity and duration registered in each rain gauge and number of paired landslides during the events of November 2013 and May 2014.

\begin{tabular}{llccr}
\hline November 2013 & Rain gauge & $\begin{array}{c}\text { Mean } \\
\text { intensity } \\
\left(\mathrm{mm} \mathrm{h}^{-1}\right)\end{array}$ & $\begin{array}{c}\text { Duration } \\
(\mathrm{h})\end{array}$ & Landslides \\
\hline \multirow{2}{*}{ Low hills } & Jesi & 4.3 & 61 & 2 \\
& Fabriano 1 & 3.5 & 69 & 1 \\
\hline \multirow{5}{*}{ Mountains } & Fabriano 1 & 3.5 & 69 & 4 \\
& Fabriano 2 & 2.4 & 63 & 1 \\
& Fabriano 3 & 3.0 & 60 & 10 \\
& Genga & 3.6 & 66 & 3 \\
& Sassoferrato & 4.6 & 68 & 14 \\
\hline \multirow{2}{*}{ May 2014 } & Rain gauge & Mean & Duration & Landslides \\
& & intensity & (h) & \\
& & $\left(\mathrm{mm} \mathrm{h}^{-1}\right)$ & & 2 \\
Low hills & Agugliano & 1.6 & 38 & 2 \\
& Cupramontana & 1.7 & 35 & 15 \\
\hline Mountains & Jesi & 2.1 & 43 & 1 \\
\hline
\end{tabular}

shows that, for a basin with such different lithologies, a generalization regarding the number of landslides expected from similar ranges of ID values is inapplicable. Hence, the considerations about the number of rainfall-triggered landslides in the low hill section of the Esino river basin cannot be exported to the mountain section; a specific rainfall threshold for this area should be developed.

From the perspective of land use influence on landsliding, the MSPA performed for this study revealed that the typologies of agricultural covers most susceptible to mass movements are crops and mixed cultivations (Table 2). In fact, in November 2013, numerous landslides were recorded in the mountains (13 in crops and 10 in mixed cultivations), while in May 2014, the low hills were the most affected (9 in crops and 10 in mixed cultivation). In terms of vegetation segmentation patterns, the core class registered the highest occurrence of landslides, with noticeable differences between the two typologies of agricultural covers. Core patterns in crops covers tallied $61.5 \%$ of occurrences in 2013 and $55.6 \%$ in 2014 , while in mixed cultivations covers they tallied $40 \%$ in 2013 and $50 \%$ in 2014 (Table 2).

The other MSPA classes showing high incidence of landslides were those with higher fragmented vegetation structures. In 2013, mass movements occurred in branch $(7.7 \%$ in crops $-20 \%$ in mixed cultivations), edge $(23.1 \%$ in crops $-20 \%$ in mixed cultivations), and bridge ( $7.7 \%$ in crops $-20 \%$ in mixed cultivations). Very similar values were recorded in 2014 (Table 2). Such results are coherent with the previous multitemporal MSPA performed over the period 1990-2006 and listed in Table 2 (Carone et al., 2015). Consequently, the areas more prone to landsliding are those showing both a higher degree of vegetation fragmentation and an intensive presence of anthropogenic low-structured vegeta- 
Table 2. Multitemporal MSPA analysis in the Esino watershed. Values represent the percentage of landslide occurrence over the different vegetation segmentations in the two most affected land cover categories: crops $(\mathrm{Cr})$ and mixed cultivations (Mix).

\begin{tabular}{|c|c|c|c|c|c|c|c|c|c|c|}
\hline \multirow{3}{*}{$\begin{array}{l}\text { Segmentation } \\
\text { classes }\end{array}$} & \multicolumn{2}{|c|}{$\begin{array}{c}1990 \\
\text { Whole basin }\end{array}$} & \multicolumn{2}{|c|}{$\begin{array}{c}\text { 1990-2000 } \\
\text { Whole basin }\end{array}$} & \multicolumn{2}{|c|}{$\begin{array}{l}\text { 2000-2006 } \\
\text { Whole basin }\end{array}$} & \multicolumn{2}{|c|}{$\begin{array}{c}2013 \\
\text { Mountains }\end{array}$} & \multicolumn{2}{|c|}{$\begin{array}{c}2014 \\
\text { Low hills }\end{array}$} \\
\hline & \multicolumn{10}{|c|}{ Land cover categories (\%) } \\
\hline & $\mathrm{Cr}$ & Mix & $\mathrm{Cr}$ & Mix & $\mathrm{Cr}$ & Mix & $\mathrm{Cr}$ & Mix & $\mathrm{Cr}$ & Mix \\
\hline Branch & 10 & 10 & 22.22 & 8.16 & 5.56 & 7.7 & 7.7 & 20 & 11.2 & 10 \\
\hline Edge & 20 & 15 & 25 & 28.57 & 16.67 & 26.92 & 23.1 & 20 & 22.3 & 30 \\
\hline Islet & 0 & 0 & 0 & 2.04 & 0 & 0 & 0 & 0 & 0 & 0 \\
\hline Core & 70 & 60 & 44.45 & 59.18 & 61.12 & 65.38 & 61.5 & 40 & 55.6 & 50 \\
\hline Bridge & 0 & 15 & 8.34 & 2.04 & 11.12 & 0 & 7.7 & 20 & 0 & 10 \\
\hline Loop & 0 & 0 & 0 & 0 & 5.56 & 0 & 0 & 0 & 11.2 & 0 \\
\hline
\end{tabular}

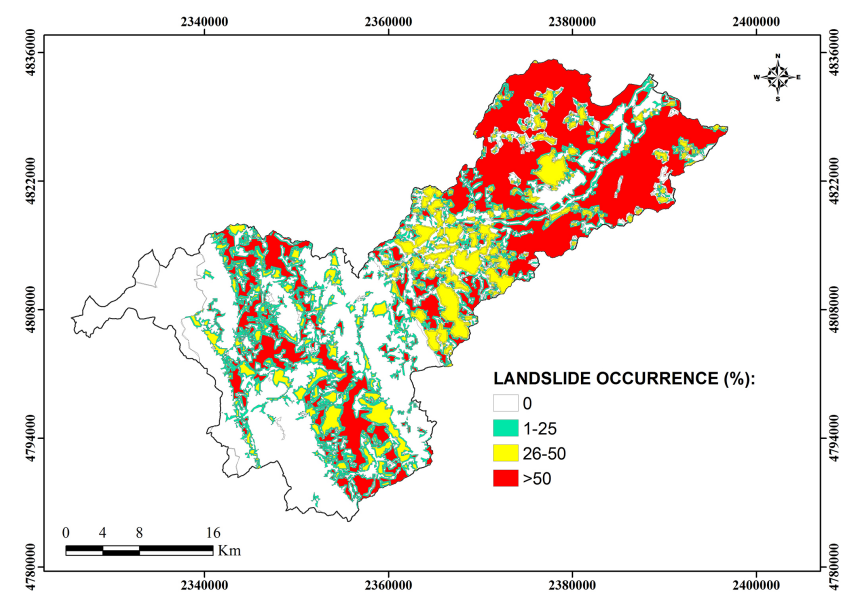

Figure 3. Landslide occurrence in crops and mixed cultivation of the Esino river basin during the November 2013 and May 2014 rainfall events. Red areas represent the vegetation segmentation classes in which more than the $50 \%$ of the landslides were recorded, yellow areas the classes in which $26-50 \%$ of the landslides were recorded, and green areas the classes in which less than $25 \%$ of the landslides were recorded. White areas are those not affected by landslides.

tion covers, such as crops and mixed cultivations. Figure 3 is a map showing the percentage of landslide occurrence in such covers for the November 2013 and May 2014 events. Given the consistency of the MSPA of this work with that of the previous study (Carone et al., 2015), we may consider such a map as a first rudimentary landslide susceptibility map of the Esino river basin.

The positive results obtained through both the intensityduration and the MSPA methods allow for their coupled use in one single empirical approach for landslide forecasting in the Esino river basin. This proposed approach consists of two consequential parts: the first concerning the analysis of the rainfall intensity and duration patterns (from weather forecasts), the second concerning the activation of landslide early-warning procedures (modulated in the territory accord- ing to the MSPA forecast of where landslides will probably occur).

\section{Conclusions}

The purpose of this study was to associate two empirical (black box) methods to predict possible landslide triggering conditions: (1) a rainfall intensity-duration threshold and (2) morphological spatial pattern analysis (MSPA) to detect the vegetation segmentation patterns more subjected to slope failures. The first posits "when" a landslide can initiate (meteoclimatic conditions), the second delimits "where" (land cover setting) a landslide can initiate. Both methods have been applied in a novel fashion to test the applicability of the coupled empirical approach. For example, the rainfall intensity-duration thresholds are usually modelled on areas from regional to global level scales, rarely at the river basin scale. At smaller scales, process-based approaches are usually applied. Thus, employing an empirical approach to a small- or medium-sized river basin was uncertain.

Notwithstanding, the ID data collected during the November 2013 and May 2014 rainfall events validated the previously modelled threshold for the Esino river basin (Gioia et al., 2015). This additional testing made evident that a further refinement of the ID threshold could be done separating the mountains from the low hills. The rainfall values recorded during the November 2013 landslide occurrences, which mainly affected the mountainous area, plotted well above the cloud of ID data of the historical landslides in the low hill area studied by Gioia et al. (2015). Considering that the rainfall values logged during the May 2014 landslide occurrences, which mainly affected the low hill area, fall within the cloud of the historical ID data, we could develop an additional threshold curve for the mountain area, maintaining Eq. (2) as a general minimum threshold curve for the Esino river basin. This choice is also supported by the different lithologies of the two areas, mainly carbonate in the mountains and post-orogenic outcrops in the low hills. 
More research effort should certainly be directed to adjust the scale of the empirical model to fit the hydrogeological setting of the study area. As a matter of fact, the significant difference between the ID values recorded in the two studied rainfall events, November 2013 and May 2014, may also be attributable to the natural variability of atmospheric seasonality.

On the other hand, the MSPA analysis showed that the agricultural covers most affected by landslides are crops and mixed cultivations, while the vegetation structures more involved are the core class, followed by the edge, branch, and bridge classes. Overall, the core areas are the most susceptible to landslides in crop cover, whereas the transitional areas (edge, branch, and bridges) become preponderant in mixed cultivations. This study was certainly subject to various limitations, including the fact that the available landslides data provided only location points. This was a constraining element of the MSPA; knowing the exact landslide areal extension would have sensibly improved the results. Nevertheless, this research reveals that anthropogenic vegetation covers and high vegetation fragmentation increase landslide susceptibility within the Esino river basin.

Coupling the intensity-duration method with the land use classification, which allows the identification of the vegetation structures that are more inclined to fail, will help reasoning about best practice in landslide mitigation, early warning mechanisms, or land use management for local authorities and civil protection. As already said, an effective integration of the two approaches will facilitate the development of landslide susceptibility maps, crucial to any disaster risk reduction strategy (from urban to emergency planning). Undeniably, the use of vegetation in mitigating landslides is emphasized by many policies. Yet, beyond the fact that vegetation is a viable measure to help stabilize slopes, not much has been discussed or been done toward the establishment of a sizeable evidence base on how vegetation structures and patterns may control landsliding processes. Such a knowledge base would be necessary to justify, for example, the spending of public money on the selection or development of different approaches to manage landslide risk.

All this said, while keeping their feet on the ground, authors acknowledge that the triggering conditions highlighted in this study are limited evidence at the moment, though they are encouraging; an empirical correlation between landslides, rainfall, and land use can be obtained expeditiously over a small-medium size river basin. Of course, these methods should be tested in other geographical settings with similar as well as different characteristics, both in terms of hydrogeology and land covers.

Acknowledgements. Authors would like to acknowledge the Centro Funzionale Multirischi della Regione Marche, and in particular Maurizio Ferretti and Gabriella Speranza for providing necessary data and the technical support to carry out the intensity-duration analysis. Authors would also like to thank the three anonymous reviewers and the editor for their constructive comments which helped to improve this manuscript greatly.

Edited by: F. Guzzetti

Reviewed by: three anonymous referees

\section{References}

Caine, N.: The Rainfall Intensity-Duration Control of Shallow Landslides and Debris Flows, Geografiska Ann. A, 62, 23-27, doi:10.2307/520449, 1980.

Carone, M. T., Gioia, E., Ferretti, M., and Marincioni, F.: Linking vegetation patterns and landslide occurrence; an empirical method, in: Engineering Geology for Society and Territory Vol. 2, Landslide Processes, edited by: Lollino, G., Giordan, D., Crosta, G., Corominas, J., Azzam, R., Wasowski, J., and Sciarra, N., Springer International Publishing, Switzerland, 1195-1198, 2015.

CFRM - Centro Funzionale Multirischi della Regione Marche: Rapporto di evento 10-13 novembre 2013, Ancona, Italy, 2013.

CFRM - Centro Funzionale Multirischi della Regione Marche: Rapporto di evento 2-4 maggio 2014, Ancona, Italy, 2014.

Coltorti, M. and Nanni, T.: La bassa valle del Fiume Esino: geomorfologia, idrogeologia e neotettonica, Boll. Soc. Geol. Ital., 106, 35-51, 1987.

Cruden, D. M. and Varnes, D. J.: Landslides Types and Processes, in: Landslides Investig. Mitigation, edited by: Turner, A. K. and Schuster, R. L., Transp. Res. Board Spec. Rep. 247, National Academy Press, Washington, D.C., 36-72, 1996.

Cucchi, A., Valsecchi, I. Q., Alberti, M., Fassi, P., Molari, M., and Mannucci, G.: The alerting system for hydrogeological hazard in Lombardy Region, northern Italy: rainfall thresholds triggering debris-flows and "equivalent rainfall" method, Nat. Hazards Earth Syst. Sci. Discuss., 3, 269-290, doi:10.5194/nhessd-3-2692015, 2015.

De Vita, P. and Reichenbach, P.: Rainfall-triggered landslides: a reference list, Environ. Geol., 35, 219-233, doi:10.1007/s002540050308, 1998.

Fell, R., Corominas, J., Bonnard, C., Cascini, L., Leroi, E., and Savage, W. Z.: Guidelines for landslide susceptibility, hazard and risk zoning for land use planning, Eng. Geol., 102, 85-98, doi:10.1016/j.enggeo.2008.03.022, 2008.

Gentili, B. and Dramis, F. (Eds): Geomorphology and Quaternary Evolution of Central Italy - Guide for the excursion, Suppl. Geogr. Fis. Dinam. Quat., 3, 79-103, 1997.

Giannecchini, R.: Relationship between rainfall and shallow landslides in the southern Apuan Alps (Italy), Nat. Hazards Earth Syst. Sci., 6, 357-364, doi:10.5194/nhess-6-357-2006, 2006.

Gioia, E., Speranza, G., Appiotti, F., Ferretti, M., and Marincioni, F.: Rainfall threshold and landslides in the post-orogenic complex of the Esino River Basin, central Italy, in: Engineering geology for society and territory - Vol. 2, Landslide Processes, edited by: Lollino, G., Giordan, D., Crosta, G., Corominas, J., Azzam, R., Wasowski, J., and Sciarra, N., Springer, Switzerland, 15531556, 2015.

Guidicini, G. and Iwasa, O. Y.: Tentative correlation between rainfall and landslides in a humid tropical environment, Bull. Int. Assoc. Eng. Geol., 16, 13-20, doi:10.1007/BF02591434, 1977. 
Guzzetti, F., Peruccacci, S., Rossi, M., and Stark, C.: Rainfall thresholds for the initiation of landslides in central and southern Europe, Meteorol. Atmos. Phys., 98, 239-267, doi:10.1007/s00703-007-0262-7, 2007.

Istanbulluoglu, E. and Bras, R. L.: Vegetation-modulated landscape evolution: effects of vegetation on landscape processes, drainage density, and topography, J. Geophys. Res., 110, F02012, doi:10.1029/2004JF000249, 2005.

Kai, L., Yuedi, S., Baohua, J., Jianjun, G., Yuqiong, W., and Dongxia, Y.: Analysis on spatial-temporal patterns of the vegetation coverages and landslides in Bailongjiang River Basin based on the Dimidiate Pixel Model, Journal of Lanzhou University, Nat. Science, 50, 376-282, 2014.

Marston, R.: Geomorphology and vegetation on hillslopes: interactions, dependencies, and feedback loops, Geomorphology, 116, 206-217, 2010.

Ministry of Environment Territory and Sea: Il Rischio Idrogeologico in Italia, available at: http://www.minambiente. it/sites/default/files/archivio/biblioteca/monografia_rischio_ idrogeologico.pdf (last access: 18 June 2015), 2008.

National Institute of Statistics - ISTAT: Population by age, sex and marital status on 1 January 2014, available at: http://demo.istat. it/pop2014/index.html, last access: 6 November 2014.
Segoni, S., Battistini, A., Rossi, G., Rosi, A., Lagomarsino, D., Catani, F., Moretti, S., and Casagli, N.: Technical Note: An operational landslide early warning system at regional scale based on space-time-variable rainfall thresholds, Nat. Hazards Earth Syst. Sci., 15, 853-861, doi:10.5194/nhess-15-853-2015, 2015.

Soille, P. and Vogt, P.: Morphological segmentation of binary patterns, Pattern Recogn. Lett., 30, 456-459, doi:10.1016/j.patrec.2008.10.015, 2009.

Strudley, M., Green, T., and Ascoughii II, J.: Tillage effects on soil hydraulic properties in space and time: State of the science, Soil Till. Res., 99, 4-48, doi:10.1016/j.still.2008.01.007, 2008.

Vogt, P.: GuidosToolbox (Graphical User Interface for the Description of image Objects and their Shapes), European Commission, Joint Research Centre (JRC), Digital image analysis software collection available at the following web site: http://forest.jrc.ec. europa.eu/download/software/guidos (last access: 18 June 2015), 2014.

Wasowski, J., Lamanna, C., and Casarano, D.: Influence of landuse change and precipitation patterns on landslide activity in the Daunia Apennines, Italy, Q. J. Eng. Geol. Hydrogeol., 43, 387401, doi:10.1144/1470-9236/08-101, 2010.

Wilson, R. C. and Wieczorek, G. F.: Rainfall thresholds for the initiation of debris flows at La Honda, California, Environ. Eng. Geosci., 1, 11-27, 1995. 